\begin{abstract}
: Durum Analizi

Bakiye KILIÇ TOPUZ1, Mehmet BOZOĞLU²

ÖZET: Türkiye'de fındık, sağladığı üretim değeri, istihdam ve ihracat geliriyle stratejik bir öneme sahiptir. Türkiye'nin fındık üretiminin \%14'ü ise Samsun İlinde gerçekleştirilmektedir. Fındık piyasalarının etkin olarak işleyebilmesi için üreticilerin yaygın ve etkili bir şekilde örgütlenmelerine ihtiyaç duyulmaktadır. Araştırmanın temel amacı, Samsun İlindeki Findık Tarımsal Üretici Birliklerinin mevcut durumu ve sorunlarının ortaya konulmasıdır. Araştırmanın ana materyalini, Samsun İlinde faaliyet gösteren 3 Organik Fındık Tarımsal Üretici Birliği yöneticilerinden ve bu birliklerin üyeleri arasından Basit Tesadüfi Örnekleme yöntemlerine göre seçilen 92 çiftçiyle yapılan anketlerden elde edilen veriler oluşturmaktadır. Araştırmada fındık üreticilerinin birlik şeklinde örgütlenmelerinin yaygın olmadığı, birliklerin gelirleri ve kârlarının çok düşük olduğu, birliklerin $2 / 3$ 'sinin üst örgütlenmesinin olmadığı, birlik yöneticilerinin genelinin eğitim seviyelerinin düşük olduğu, birlik üyelerinin sorumluluklarını yaygın olarak yerine getirmedikleri ortaya konulmuştur. Bununla birlikte, birliklerin ürün pazarlama, girdi temini ve ihracatta üyelerine sadece aracı oldukları, herhangi bir dış kaynaklı proje yürütmedikleri belirlenmiştir. Fındık Tarımsal Üretici Birliklerinin geliştirilebilmesi için kendilerine projeye dayalı finansal ve teknik yardımların sağlanarak rekabet güçlerinin artırılması gerekli görülmektedir.
\end{abstract}

Anahtar Kelimeler: Durum analizi, fındık, sorun analizi, tarımsal üretici birliği, Samsun.

\title{
Analysis of Current Situation of the Hazelnut Agricultural Producer Unions in Samsun Province
}

\begin{abstract}
Hazelnut has a strategic importance in Turkey with its production value, employment and export revenue. Samsun Province produced 14\% of Turkey's hazelnut production. In order to establish competition condition in hazelnut markets, producers should be organized effectively. The main aim of this research was to expose the current situation and problems of the Hazelnut Agricultural Producer Unions (APU) in Samsun province. The data of this study were collected through surveys from both the board members of 3 unions and 92 members of the unions which were randomly selected. The research results showed that the hazelnut producers were not widely organized under the unions, incomes and profits of the unions were very low, $2 / 3$ of the unions were a member of upper organization, education level of union's board members were very low, the members did not effectively fulfill their responsibilities. However, it was found that the unions just mediate to supply inputs and to market members' crops and they did not carry out a project. In order to develop the unions' competitiveness, the unions should be provided project-based financial and technical assistance.
\end{abstract}

Keywords: Agricultural producer unions, case analysis, hazelnut, problem analysis, Samsun.

Bakiye KILIÇ TOPUZ (0000-0002-3607-4306), Iğdır Üniversitesi, Ziraat Fakültesi, Tarım Ekonomisi Bölümü, Iğdır, Türkiye

Mehmet BOZOĞLU (0000-0001-8333-1865), Ondokuz Mayıs Üniversitesi, Ziraat Fakültesi, Tarım Ekonomisi Bölümü, Samsun, Türkiye Sorumlu yazar/Corresponding Author: Bakiye KILIÇ TOPUZ, bakiyekilic@hotmail.com 


\section{GíRiş}

Dünya'da 2014 yılı itibariyle 927 bin ha alanda 736 bin ton fındık üretimi gerçekleşmiştir. Dünya fındık dikim alanlarının \%75'ine sahip olan Türkiye üretimin de \%61'ini gerçekleştirmiştir (Anonymous, 2014a). Türkiye'de 2015 yılı itibariyle 33 ildeki 502 bin işletmede 646 bin ton findık üretimi gerçekleştirilmiştir (Anonim, 2017). Türkiye'de fındık üretiminde doğrudan veya dolaylı olarak yaklaşık 4 milyon kişi istihdam edilmektedir (Anonymous, 2014b). Samsun İlindeki 895 bin da alanda 91 bin ton fındık üretilmiş olup, bu miktar Türkiye'deki üretimin \%14'ünü oluşturmaktadır (Anonim, 2017). Samsun ilinde üretilen findığın \%52'si Çarşamba, \%21'i Terme, $\% 11$ 'i Salıpazarı, \%4'ü Tekkeköy ve \%3'ü ise 19 Mayıs ilçesinde gerçekleştirilmiştir (Anonim, 2016b).

Tarımdaki üreticilerin örgütlenmesi, üreticilerin sorunlarına çözüm bulma, tarım politikalarına yön verme, üretim planlamasının yapılması, maliyetlerin azaltılması, pazarlama sorunlarına çözüm bulma, aracıların kâr marjlarının azaltılması ve üreticilerin eline daha yüksek fiyat geçebilmesi açısından zorunluluk arz etmektedir. Samsun İlindeki fındık üreticileri, Fındık Tarım Satış Kooperatifleri (FISKOBIRLIKK) ve Fındık Tarımsal Üretici Birlikleri (TÜB) şeklinde bir araya gelerek örgütlenmektedirler. Türkiye'de FİSKOBIRLİK 1938 yılında, TÜB'leri ise 2005 yılında kurulmaya başlanmıştır. Samsun ilinde ise FISKOBİRLIK yalnızca Çarşamba ve Terme ilçelerinde, TÜB ise Çarşamba, Terme ve 19 Mayıs ilçelerinde bulunmaktadır (Anonim, 2014). Türkiye'nin en önemli ihraç ürünlerinden olan findık tarımında sorunlara çözüm bulabilmek ve fındık piyasalarının etkin olarak işleyebilmesi için üreticilerin etkili olarak örgütlenmeleri kaçınılmazdır. Özellikle son yıllarda Türkiye'nin dünya fındık üretiminde lider konumdan uzaklaşması, rekabetçi ülkelerde fındık üretimindeki artışlar bu konuda örgütlenmeyi gerekli kılmaktadır. TÜB, 5200 Sayılı Kanuna göre tarım üreticilerinin gönüllülü̈k esasına dayalı olarak ürün veya ürün grubu bazında ve asgari ilçe düzeyinde kurdukları tüzel kişiliğe haiz örgütlerdir (Anonim, 2004).

Literatür incelendiğinde tarımsal üretici birlikleri ile ilgili alan araştırmalarının oldukça sınırlı sayıda olduğu (Güreşçi, 2010; Doğan, 2011; Çukur ve Saner, 2012) belirlenmiştir. Bu araştırmaların tamamına yakını, tarımsal üretici birliklerinin kayıtlarından elde edilen ikincil verilere dayanmakta (Güreşçi, 2010; Çukur ve Saner, 2012), Doğan (2011) ise yaş meyve ve sebze tarımsal üretici birliği üyeleriyle ankete dayalı bir çalışması bulunmaktadır. Buna karşın, Türkiye'de fındık tarımsal üretici birliklerine yönelik herhangi bir araştırmaya ise rastlanılmamıştır. Araştırmanın temel amacı, Samsun İlindeki Fındık TÜB'nin mevcut durumu ve sorunlarının ortaya konulmasıdır.

\section{MATERYAL VE YÖNTEM}

Araştırmanın ana kitlesini, Samsun İlinde bulunan 3 Organik Fındık TÜB ve bu birliklere üye olan 1,970 fındık üreticisi oluşturmaktadır. Örnekleme kriteri olarak birlik üyelerinin fındık arazisi miktarları (da) esas alınmıştır. Örnek sayısı, Basit Tesadüfi Örnekleme Metodu'na göre aşağıdaki formül yardımıyla hesaplanmıştır (Yamane, 1967).

$$
\mathbf{n}=\frac{\mathbf{N}(\mathrm{zC})^{2}}{\mathbf{N ~ d}^{2}+(\mathrm{zC})^{2}}
$$

Formülde, $\mathrm{N}$ ana kitledeki işletme sayısını, $\mathrm{z}$ istenen güven derecesine karşıllık gelen standart normal dağılım değerini (1.645), C varyasyon katsayısını (standart sapma/ortalama), d araştırmada kabul edilen hata payını $\left({ }^{ \pm} \% 10\right), \mathrm{n}$ ise gerekli örnek sayısını ifade etmektedir.

Araştırmada kabul edilen hata payı \%10 olup, \%95 güven aralığında toplam örnek hacmi 92 olarak hesaplanmıştır. Araştırmanın birincil verileri, belirlenen 3 Organik Fındık TÜB yöneticilerinden ve 92 birlik üyesi üreticilerle Haziran-Eylül 2014 tarihleri arasında yüz yüze yapılan anketlerden elde edilmiştir. Birlik üyelerinin \%66'sı Çarşamba Organik Fındık TÜB, \%19'u 19 Mayıs Organik Fındık TÜB ve $\% 15$ 'i ise Terme Organik Fındık TÜB üyelerinden oluşmaktadır. $\mathrm{Bu}$ araştırmada KMO değerinin 0.957 olması, örneklemin yüksek derecede yeterli olduğunu göstermektedir. Araştırmanın ikincil verileri ise Gıda, Tarım ve Hayvancılık Bakanlığı (GTHB), Türkiye İstatistik Kurumu, Samsun Gıda, Tarım ve Hayvancılık İl Müdürlüğü ve Resmi Gazete gibi kurum ve kuruluşlardan elde edilmiştir. Bununla birlikte, araştırmada konu ile ilgili yerli ve yabancı literatür, tez, rapor vb. kaynaklardan da materyal olarak yararlanılmıştır.

Proje Döngüsü Yönetimi (PDY), bir proje fikrinin ortaya çımasından projenin tamamlanmasına kadar geçen süre içerisindeki tüm aşamaları kapsayan bir kavramdır. PDY'nin başarılı bir şekilde 
gerçekleşebilmesi Mantıksal Çerçeve Yaklaşımı (MÇY) kullanılmasına bağlıdır. MÇY, analiz ve planlama aşamalarından oluşmaktadır. Analiz aşaması ise beş aşamadan oluşmaktadır. Birinci aşama, mevcut durum analizi, ikinci aşama sorun analizi, üçüncü aşama paydaş analizi, dördüncü aşama amaç analizi ve beşinci aşama da strateji analizidir. Mevcut durum analizi, proje alanı ve hedef grupla ilgili genel durumun belirlenmesi ve sorunların ortaya konulmasidır (European Commission, 2002). Bu araştırma kapsamında MÇY aşamalarından mevcut durum analizi yöntemi kullanılmıştır ve TÜB'nin mevcut durum analizi yapılmıştır.

\section{BULGULAR VE TARTIŞMA}

\section{Birlikler, Yöneticiler ve Birlik Üyeleri ile İlgili Genel Bilgiler}

Araştırma kapsamında ele alınan Organik Fındık TÜB'nin 2005 yılında kurulmaya başlamış, ortalama 656 üyeye sahip ve ortalama 51 köye hizmet vermektedirler. Çukur ve Saner (2012) tarafından Muğla İlinde yapılan çalışmada; Milas İlçesi Süt Birliği'nin 2,493 üyesinin olduğu ve 66 köye hizmet verdikleri tespit edilmiştir. Araştırmada Fındık TÜB'ne kayıtlı üye sayısı yüksek olmasına rağmen, üyelerin \%38'inin aktif olmadığ tespit edilmiştir. Kılıç (2011) tarafından aynı bölgede tarımsal kalkınma kooperatifleri ile yapılan araştırmada aktif üye oranı $\% 69$ olup, TÜB'deki aktif üye oranı kooperatiflere kıyasla daha düşüktür. Gül-Gülyağı ve Yağlı Tohumlar Tarım Satış Kooperatifleri Birliği (GÜLBİRLIK) ortakları ile yapılan bir başka çalışmada da aktif ortak oran $\% 62$ olarak tespit edilmiştir (Ertan ve Turan, 2001). Birlik yöneticileri ise ortalama 52 yaşında ve ortaokul düzeyinde eğitim seviyesine sahiplerdir.
Birliklerin \%66'sının yöneticileri, ilkokul düzeyinde eğitim seviyesine sahiptir. Erkuş ve Özüdoğru (2005) tarafından Köy-Koop Kırklareli Birliği'nde 14 tarımsal kalkınma kooperatif yöneticileriyle yapılan araştırmada kooperatif yöneticilerinin \%60'ının ilkokul, \%40'ınınise lise mezunu, Everest (2009)'in Çanakkale İlinde yaptığı çalışmada ise kooperatif yöneticilerinin \%67.6'sının ilkokul, \%6.8'inin üniversite mezunu olduğu ortaya konulmuştur. Tekirdağ İlinde yapılan diğer bir çalışmada (Başaran, 2003), kooperatif yöneticilerinin $\% 29.3$ 'ünün ilkokul ve \%22'sinin üniversite mezunu, Karlı ve Çelik (2003)'ın çalışmasında ise tarımsal kalkınma kooperatifi yöneticilerinin \%17.6'sının ilkokul, \%64.8'inin ise lise mezunu olduğu tespit edilmiştir. Karami and Moghaddam (2005) tarafından İran'da tarım kooperatifleri üzerine yapılan araştırmada ise kooperatif yöneticilerinin ortalama 15 yıl eğitim seviyesine sahip olduğu belirlenmiştir. Bu sonuçlardan Samsun İlindeki TÜB yöneticilerinin eğitim düzeyinin Çanakkale ve Kırklareli kooperatif yöneticileri ile aynı, Tekirdağ, GAP Bölgesi ve İran tarımsal kooperatif yöneticilerinden ise daha düşük olduğu anlaşılmaktadır. Birlik yöneticilerinin eğitim seviyesi düşük kişilerden olması, birliklerin başarısı önünde büyük engel olduğu düşünülmektedir. Araştırmada \%1'i kadın, \%99'u ise erkek olan birlik üyelerinin ortalama yaşı 55 ve eğitim seviyeleri ise ilkokul düzeyindedir. Hane halk1 büyüklükleri 3,75 kişi olup, \%90'ının asıl işi çiftçiliktir ve 33 yıldır tarımla uğraşmaktadırlar. Birlik üyelerinin 37 bin TL tarımsal, 9 bin TL tarım dışı olmak üzere ortalama 46 bin TL yıllık gelirleri bulunmaktadır. Findık üreticilerinin ortalama 40 da araziye sahip oldukları ve bu arazinin \%72'sinin mülk, \%24'ünün ortağa tutulan ve \%4'ünün ise kiraya tutulan araziden oluştuğu belirlenmiştir.

Çizelge 1. Birlikler, yöneticiler ve birlik üyeleri ile ilgili genel bilgiler

\begin{tabular}{|c|c|c|c|c|c|c|c|c|c|}
\hline & \multicolumn{5}{|c|}{ Birlik } & \multicolumn{2}{|c|}{ Yönetici } & \multicolumn{2}{|c|}{ Birlik üyeleri } \\
\hline Organik Fındık TÜB & 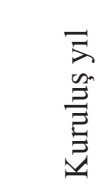 & 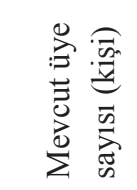 & 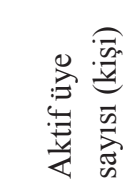 & 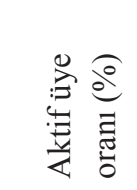 & 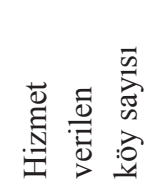 & $\stackrel{\mathbb{Z}}{\sim}$ & 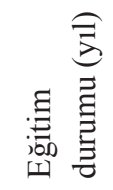 & $\stackrel{\pi}{\pi}$ & 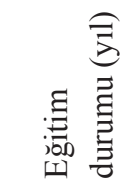 \\
\hline Çarşamba & 2007 & 1,447 & 800 & 55.2 & 121 & 49 & 5 & 58 & 5.4 \\
\hline 19 Mayıs & 2005 & 320 & 320 & 100.0 & 15 & 45 & 5 & 54 & 6.1 \\
\hline Terme & 2005 & 203 & 106 & 52.2 & 18 & 62 & 16 & 55 & 7.3 \\
\hline Toplam & - & 656 & 408 & 62.1 & 51 & 52 & 8 & 55 & 6.2 \\
\hline
\end{tabular}




\section{Birliklerin Amaçları ve Üst Örgütlenme Du- rumları}

Birliklerin öncelikli amaçları; ürün kalitesini iyileştirmek, kendi mülkiyetine almadan pazara ürün sevk etmek ve ürünlerin pazarlama gücünü artırıcı tedbirler almak şeklinde belirlenmiştir. Birliklerin diğer öncelikli amaçları; üretici örgütlenmesini ve üretimi artırmak, ürünleri yüksek fiyatla pazarlamak, istihdama katkı sağlamak ve yeni ürün çeşitleri üretmek şeklindedir. İlgili kanunda yer verilmesine rağmen, üretimi talebe göre planlamanın birliklerin öncelikli amaçları arasında yer almadı ğı tespit edilmiştir (Çizelge 2). Acar ve Yıldırım'ın (2000) araştırmasındaki kooperatiflerde ortakların sütünü pazarlamak ve ihtiyaç duyulan bazı girdileri uygun koşullarda ortaklara temin etmek, Özüdoğru'nun (2004) çalışmasında ise ürün alımı, tüketim, satış, işleme, kredi ve sigorta gibi daha geniş hizmetleri ortaklara sağlanmak şeklinde amaçlar öne çıkmıştır.

Fındık konusunda faaliyet gösteren birliklerin Meyve Üreticileri Merkez Birliği (MB)'ne üyelik durumları incelendiğinde; Merkez Birliğine sadece 19 Mayıs Fındık TÜB'nin üye olduğu, diğer iki birliğin ise üye olmadığı tespit edilmiştir. Birliklerin MB'ne üye olmama sebepleri; MB'ne güvenilmemesi ve MB'nin ürün grubu değil ürün bazında kurulması gerektiğinin düşünülmesidir.

Çizelge 2. Birliklerin temel amaçları

\begin{tabular}{|c|c|c|c|c|}
\hline Amaçlar & 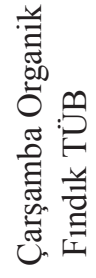 & 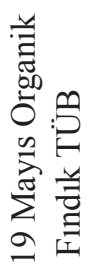 & 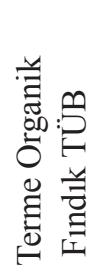 & $\frac{\overbrace{0}^{0}}{\frac{\pi}{0}}$ \\
\hline Üretimi talebe göre planlamak* & + & & & 33.3 \\
\hline Ürün kalitesini iyileştirmek* & + & + & + & 100.0 \\
\hline Kendi mülkiyetine almadan pazara ürün sevk etmek* & + & + & + & 100.0 \\
\hline Ürünlerin pazarlama gücünü artırıcı tedbirler almak* & + & + & + & 100.0 \\
\hline Üretici örgütlenmesini artırmak & & + & & 33.3 \\
\hline Üretimi artırmak & & & + & 33.3 \\
\hline Ekolojik ilçe kurmak & + & & & 33.3 \\
\hline Ürünleri ambalajlı ve yüksek fiyatla satmak & + & & & 33.3 \\
\hline İstihdama katk1 sağlamak & + & & & 33.3 \\
\hline Üreticiyi bilinçlendirmek & & + & & 33.3 \\
\hline Yeni ürün çeşitleri üretmek & & + & & 33.3 \\
\hline
\end{tabular}

* 5200 S.K. yer alan TÜB'leri amaçlarıdır.

\section{Birliklerin Gelir ve Gider Durumları}

Tarımsal örgütlerin üyelerine daha fazla hizmet sağlayabilmeleri ve varlıklarını devam ettirebilmeleri, örgütlerin yeterli bir şekilde finanse edilebilmesine bağlıdır. TÜB'nin gelirleri 5200 Sayılı Kanun'a göre; üyelik aidatları, üyelere sağlanan danışmanlık hizmetleri karşıllı̆̆ında alınan ücretler, yurt içi ve yurt dışından sağlanan bağış, fon ve yardımlar, taşınır-taşınmaz mallardan elde edilen gelirler, reklam, tanitım ve yayın gelirleri ve birlik aracılığılya pazarlanan ürünlerin satış bedeli üzerinden kesilecek hizmet payından oluşmaktadır (Anonim, 2004). Araştırma kapsamında ele alınan birliklerin ortalama 184 bin TL gelire sahip oldukları ve bu gelirin büyük çoğunluğunun (\%73) 
danışmanlık hizmetleri karşılığında alınan ücretlerden oluştuğu belirlenmiştir. Birliklerin gelirlerinin \%16's1 üyelik aidatlarından, \%7'si bağış, fon ve yardımlardan ve \%4'ü de ürün pazarlamaya aracılıktan dolayı elde edilen gelirlerden oluşmaktadır (Çizelge 3).

GTHB tarafından 2015/19 nolu tebliğ kapsamında, tarım işletmelerine tarımsal danışmanlık hizmeti sunan kişi ve kuruluşlara destek verilmektedir. Bu kapsamda belirli koşulları yerine getiren tarım işletmelerine yılda 600 TL ödeme yapılmaktadır. Araştırmanın yapıldı ̆̆ yıl üretici örgütleri ve ziraat odaları, tarımsal danışmanlık dernekleri veya vakıfları ve tarımsal danışmanlık şirketleri en fazla 8 tarım danışmanı istihdam edebilmekteydiler (Anonim, 2015). Ancak
2016 yılında çıkarılan bir kanunla üretici örgütlerinde tarım danışmanı istihdamına sınır getirilerek en fazla 5 kişiye düşürülmüştür (Anonim, 2016a). Oysa, birliklerin görev ve sorumluluklarını tam anlamıyla yerine getirebilmek için tarım danışmanları büyük önem taşımaktadır. Bu sebeple, birliklerde istihdam edilen tarım danışmanı sayısı artırılmalı ve danışmanlık desteği devam ettirilmelidir. TÜB'de toplam 29 ve ortalama 9 kişi istihdam edildiği ve bu istihdam edilen kişilerin tarım danışmanlarından oluştuğu belirlenmiştir. $\mathrm{Bu}$ sebeple, birliklerin gelirlerinin tamamına yakınını oluşturan danışmanlık hizmetleri karşıllı̆̆ alınan ücretler, danışmanlara maaş, sigorta ve yol masrafı olarak geri ödendiğinden birliklerin yıllık kârları, 9 bin TL'ye düşmektedir.

Çizelge 3. Birliklerin gelir ve giderleri

\begin{tabular}{|c|c|c|c|c|c|c|c|c|c|c|c|}
\hline \multirow[t]{2}{*}{$\begin{array}{l}\text { Organik } \\
\text { Fındık } \\
\text { TÜB }\end{array}$} & \multicolumn{2}{|c|}{$\begin{array}{l}\text { Üyelik } \\
\text { Aidatları }\end{array}$} & \multicolumn{2}{|c|}{$\begin{array}{c}\text { Danışmanlık } \\
\text { Hizmetleri }\end{array}$} & \multicolumn{2}{|c|}{$\begin{array}{c}\text { Yurt İçi/Dışı } \\
\text { Bağış, } \\
\text { Fon ve Yardımlar }\end{array}$} & \multicolumn{2}{|c|}{$\begin{array}{c}\text { Ürün } \\
\text { Pazarlama }\end{array}$} & \multicolumn{3}{|c|}{$\begin{array}{c}\text { Toplam } \\
\text { Finansman }\end{array}$} \\
\hline & $\begin{array}{c}\text { Tutar } \\
\text { (Bin TL) }\end{array}$ & $\begin{array}{l}\text { Oran } \\
(\%)\end{array}$ & $\begin{array}{c}\text { Tutar } \\
\text { (Bin TL) }\end{array}$ & $\begin{array}{l}\text { Oran } \\
(\%)\end{array}$ & $\begin{array}{c}\text { Tutar } \\
\text { (Bin TL) }\end{array}$ & $\begin{array}{l}\text { Oran } \\
(\%)\end{array}$ & $\begin{array}{c}\text { Tutar } \\
\text { (Bin TL) }\end{array}$ & $\begin{array}{l}\text { Oran } \\
(\%)\end{array}$ & $\begin{array}{c}\text { Gelir } \\
(\text { Bin TL) }\end{array}$ & $\begin{array}{c}\text { Gider } \\
(\mathrm{Bin} T L)\end{array}$ & $\begin{array}{c}\text { Kâr } \\
\text { (Bin TL) }\end{array}$ \\
\hline Çarşamba & 50 & 12.0 & 360 & 85.0 & - & - & 10 & 3.0 & 420 & 400 & 20 \\
\hline 19 Mayıs & 20 & 23.0 & 60 & 69.0 & - & - & 6,5 & 8.0 & 87 & 85 & 2 \\
\hline Terme & 6 & 13.0 & 30 & 65.0 & 10 & 21.0 & - & - & 46 & 40 & 6 \\
\hline Toplam & 76 & - & 450 & - & 10 & - & 16,5 & - & 553 & 525 & 28 \\
\hline Ortalama & 25 & 16.0 & 150 & 73.0 & 3,3 & 7.0 & 5,5 & 3.66 & 184 & 175 & 9 \\
\hline
\end{tabular}

Türkiye'deki tarımsal örgütlerin etkili bir şekilde gelişme gösterememesinin en önemli nedenlerinden biri olarak, sermaye yetersizliği görülmektedir (Özüdoğru, 2004; Rehber, 2006; Kılıç, 2011). Tarımsal örgütlerin sermaye yetersizliğinin en önemli nedeni ise üyelerin sermaye katkısının yetersiz olmasından kaynaklanmaktadır.

Tarımsal örgütlerin en önemli finansman kaynakları üyelerin sağlayacağı giriş sermayesi ve aidatlardır. Araştırma kapsamında incelenen birliklerin yalnızca \%33.3'ünde üyelerden giriş sermayesi alınmaktadır. Üyelik aidatı ise birliklerin tamamında alınırken, ortalama olarak 118 TL'dir. Birlik üyelerinin yaklaşık yarısı üyelik aidatını ya hiç ödememekte ya da ara sıra ödemektedirler. Bu durum, birliklerin gelirlerinde azalmaya ve dolayisıyla birliklerin piyasada rekabet güçlerinin azalmasına sebep olmaktadır.

Birliklerine üyelik aidatı ödeyen üyelerin oranı yalnızca \%20'dir ve sadece 19 Mayıs Fındık TÜB'nde üyelerin tamamı birliklerine her zaman üyelik aidatı ödemektedirler (Çizelge 4). TÜB'lerin hiçbiri yedek akçe ayırmamaktadırlar. Oysa birliklerin yıllık gelirlerinin bir kısmını düzenli olarak yedek akçe olarak ayırmaları gerekmektedir. 
Çizelge 4.Birliklerde giriş sermayesi alınma, üyelik aidatı ödenme durumları

\begin{tabular}{|c|c|c|c|c|c|c|c|c|c|c|}
\hline \multirow[t]{2}{*}{$\begin{array}{l}\text { Organik } \\
\text { Fındık TÜB }\end{array}$} & \multicolumn{2}{|c|}{$\begin{array}{c}\text { Giriş̧ } \\
\text { sermayesi }\end{array}$} & \multirow{2}{*}{$\begin{array}{c}\begin{array}{c}\text { Üyelik } \\
\text { aidatı }\end{array} \\
\text { Alınma } \\
\text { durumu }\end{array}$} & \multicolumn{4}{|c|}{$\begin{array}{c}\text { Üyelik aidatı } \\
\text { ödeme sıklıkları (\%) }\end{array}$} & \multicolumn{3}{|c|}{$\begin{array}{l}\text { Üyelik aidatı ödenen miktar } \\
\text { (TL/yıl) }\end{array}$} \\
\hline & $\begin{array}{l}\text { Alınma } \\
\text { durumu }\end{array}$ & $\begin{array}{l}\text { Miktar } \\
\text { (TL) }\end{array}$ & & $\begin{array}{l}\text { Hiçbir } \\
\text { zaman }\end{array}$ & $\begin{array}{l}\text { Ara } \\
\text { sira }\end{array}$ & Genellikle & $\begin{array}{c}\text { Her } \\
\text { zaman }\end{array}$ & $\begin{array}{c}\text { En az } \\
\text { ödenen }\end{array}$ & $\begin{array}{l}\text { En çok } \\
\text { ödenen }\end{array}$ & $\begin{array}{l}\text { Genellikle } \\
\text { ödenen }\end{array}$ \\
\hline Çarşamba & - & - & + & 20.0 & 50.0 & 30.0 & - & 100 & 100 & 100 \\
\hline 19 Mayıs & + & 150 & + & - & - & - & 100.0 & 100 & 200 & 150 \\
\hline Terme & - & - & + & 10.0 & 60.0 & 30.0 & - & 100 & - & 105 \\
\hline Ortalama & 33.3 & - & 100.0 & 10.0 & 36.6 & 20.0 & 33.3 & 100 & 100 & 118 \\
\hline
\end{tabular}

\section{Birliklerin Yasal Görevlerini Yerine Getirme Durumları}

TÜB'ün tabi olduğu 5200 Sayılı Kanun'un 5. Maddesinde birliklerin görevleri belirtilmiştir. Araştırma kapsamında incelenen birliklerin kanuni görevlerini yerine getirme durumları Çizelge 5'de verilmiştir. İncelenen birliklerin, ürünlerle ilgili her türlü kaydı tutmak ve iç pazar ve ihracata uygun çeşitlerin üretilmesini sağlamak, çevreyle uyumlu üretim tekniklerini yaygınlaştırmak, tarımsal uygulamaları izlemek, kayıtlarını tutmak ve belge düzenlemek, ürün kalitesini iyileştirici tedbirler almak, ürün depolama, gerektiğinde depo kiralanmasına yardımcı olma gibi görevlerini etkili olarak yerine getirdikleri belirlenmiştir. Buna karşın, TÜB'lerin üyelerine girdi temininde yardımda bulunmak, üyelere teknik destek sağlamak, uluslararası ürüne özgü ortak piyasa düzenlemelerinin gerektirdiği görevleri yürütmek, paket ve ambalajlarla ilgili standartların uygulanmasını sağlamak gibi görevlerini ise etkili bir şekilde yerine getirmedikleri tespit edilmiştir. Kanunda belirtilen görevleri yerine getirmede en başarılı birlik 19 Mayıs Fındık TÜB iken, en başarısız birlik ise Terme Organik Fındık TÜB'dir.

Çizelge 5. Birliklerin 5200 S.K.'da yer alan görevleri yerine getirme durumu

\begin{tabular}{|c|c|c|c|c|c|}
\hline $\begin{array}{l}5200 \text { S.K. } \\
\text { yer alan görevler }\end{array}$ & 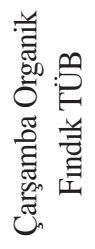 & 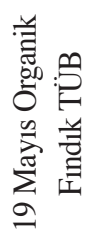 & 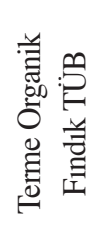 & 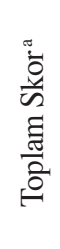 & 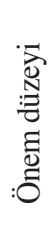 \\
\hline Tarımsal uygulamaları izler, kayıtlarını tutar ve belge düzenler. & 5 & 5 & 4 & 14 & 2 \\
\hline Ürünlerle ilgili her türlü kaydı tutar. & 5 & 5 & 5 & 15 & 1 \\
\hline Ürün kalitesini iyileştirici tedbirler alır ve ürün standartlarını uygular. & 5 & 5 & 4 & 14 & 2 \\
\hline Ürün piyasa araştırması yapar ve yaptırır. & 5 & 5 & 4 & 14 & 2 \\
\hline Ürünlere pazar bulur ve pazara arzını düzenler. & 5 & 5 & 4 & 14 & 2 \\
\hline Üyelerine eğitim-yayım hizmeti verir ve danışman hizmeti sağlar. & 5 & 5 & 4 & 14 & 2 \\
\hline Üyelerine girdi temininde yönlendirici yardımlarda bulunur. & 4 & 5 & 4 & 13 & 3 \\
\hline Üyelerine teknik destek sağlar. & 4 & 5 & 2 & 11 & 4 \\
\hline Çevreyle uyumlu üretim tekniklerini yaygınlaştırır. & 5 & 5 & 5 & 15 & 1 \\
\hline Ürünlerin tanıtımıyla ilgili faaliyetlerde bulunur. & 5 & 5 & 4 & 14 & 2 \\
\hline İç pazar ve ihracata uygun çeşitlerin üretilmesini sağlar. & 5 & 5 & 5 & 15 & 1 \\
\hline Uluslararası ürüne özgü ortak piyasa düzenlemelerinin gerektirdiği görevleri yürütür. & 4 & 5 & 4 & 13 & 3 \\
\hline Ürün depolanmasına, gerektiğinde depo kiralanmasına yardımcı olur. & 5 & 4 & 5 & 14 & 2 \\
\hline Sözleşmeli üretimle ilgili faaliyetleri koordine eder. & 4 & 5 & 5 & 14 & 2 \\
\hline Paket ve ambalajlarla ilgili standartların uygulanmasını sağlar. & 1 & 1 & 1 & 3 & 5 \\
\hline Toplam skor $^{\mathrm{a}}$ & 67 & 70 & 60 & - & - \\
\hline
\end{tabular}

${ }^{a}$ Toplam skor, yöneticilerin 5200 SK yer alan görevleri ilgili her bir soruya verdikleri cevapların ă̆ırllklı toplamları alınarak hesaplanmıştır. Birlik görevlerini yerine getirme durumları, 1 (kesinlikle katılmıyorum)'den 5 (kesinlikle katıllyorum)'e kadar değişmektedir. 


\section{Birliklerin Üyelerine Sağladıkları Hizmetler ve Üyelerin Bu Hizmetlerden Yararlanma Durumları}

Birliklerin tamamı üyelerine ürün pazarlamaya ve ihracata aracılık hizmeti sağlarken, pazarlanan ürünlerde ihracatın payı oldukça düşük (\%31) kalmaktadır. İncelenen birliklerin tamamı, Alman RAPUNZEL firması aracılığıyla organik fındık ihracatı yapmaktadır. Pazarlanan ürünlerde 2013 yılı ihracatın payı ise Terme Organik Findık ÜB'nde ise \%50, Çarşamba Organik Fındık ÜB'nde \%33 ve 19 Mayıs Organik Fındık ÜB'nde ise \%10'dur. Organik findık ihracatı 2011 yılında başlamış olup, günümüzde organik fındık talebi ve üretici sayısının artmasının etkisiyle ihracatta da artış yaşanmaktadır. Organik fındık ürün grubundaki birlik üyelerinin en önemli sorunlarından biri, ihracat yapılan firmanın kotasının olmasıdır. Firmanın kotası dolduğunda üyelerden organik fındık alınmamakta ve üyelerde ürünü tüccara konvansiyonel fındık ile aynı fiyatta pazarlamaktadırlar. Bu noktada organik fındık üretici birliklerinin alternatif firmalar bularak piyasada rekabet yaratması kaçınılmazdır. Aksi halde ürününü organik olarak pazarlayamayan üyeler bundan birliği sorumlu tutmakta ve birliğe karşı güveni, bağlılığı ve memnuniyeti azalmaktadır. Birlik üyelerinin yalnızca \%38'inin piyasa fiyatından daha yüksek fiyat ile fındıklarını TÜB aracılı̆̆ 1 ile ihracat yaptığı, \%62'sinin yapamadığı tespit edilmiştir.

Birliklerin tamamı girdi temininde yönlendirici yardımda bulunmasına rağmen, birliklerin yalnızca birinde girdi temini hizmeti bulunmaktadır. Buna rağmen, üyelerin birliklerin girdi temininde yönlendirici yardımda bulunma hizmetinden faydalanma oranı ise yok denecek kadar azdır (\%1.1). Birliklerin tamamı üyelerine yılda ortalama $3 \mathrm{kez}$ organik tarım, iyi tarım ve bitkisel üretim sorunları konularında eğitim düzenlemesine rağmen, üyelerin birliklerin eğitim hizmetlerinden yararlanma oranları \%42'dir. Üretici örgütlenmesi konusunda 3 birliğin 2'si üyelerine eğitim hizmeti sağlamasına rağmen, birlik üyelerinin sadece $\% 8$ 'i bu eğitimden yararlanmıştır. Ayrıca, birlik yöneticileri de ortalama $4 \mathrm{kez}$ üretici örgütlenmesi konusunda eğitim almışlardır (Çizelge 6). Oysa, hem birlik yöneticilerinin hem de birlik üyelerinin örgütlenme bilincinin artırılabilmesi için eğitilmeleri kaçınılmazdır.

Güreşçi (2010)'nin Erzurum'un İspir İlçesinde yaptığı araştırmada Bal ÜB üyelerin kaydının tutulması, proje hazırlanması, üyelere arıcılık ekipmanlarının sağlanması, modern arıcılı̆̆ın uygulanması, ulusal ve uluslararası eğitimlere katılma, bölge balının standardı ve sertifikasının oluşturarak piyasaya sürülmesi vb. faaliyetlerinin olduğu ortaya konulmuştur. Çukur ve Saner (2012)'in Muğla'nın Milas İlçesi Süt ÜB'deki araştırmalarında da birliğin üyelerin kayıtlarının tutulması, kaliteli süt üretimi, süt fiyatlarının belirlenmesinde borsa görevi, eğitim ve danışmanlık hizmeti, çiftlik ve tarla günü çalışmaları, ürün pazarlama, girdi temini, süt ödemelerinin zamanında yapılması, üyelerin tarımsal desteklerden yararlanmaları, üreticisektör buluşmasının gerçekleştirilmesi gibi faaliyetleri bulunmaktadır. Erkuş ve Özüdoğru (2005)'nun KöyKoop Kırklareli Birliği ile ilgili araştırmalarında birliğin bölgedeki süt fiyatlarının belirlenmesi, birim kooperatiflerden günlük süt toplanması ve pazarlanması, ortaklara vadeli girdi ve tüketim maddelerinin sağlanması şeklinde hizmetleri bulunmaktadır. Bozoğlu ve ark. (2001)'nin Trabzon'un Tonya ilçesindeki tarımsal kalkınma kooperatifin ortaklarına süt işleme ve süt ürünlerini pazarlama, daha ucuza girdi temin etme, girdi ve ürün piyasalarında rekabet ortamı yaratma gibi hizmetleri sağlandığını belirtmişlerdir. Buradan araştırma kapsamında incelenen birliklerin sağladıkları hizmetlerin daha kısıtll olduğu ifade edilebilir.

Birliklerin sadece birinin web sitesi bulunmaktadır. Araştırmada ele alınan birliklerden Çarşamba Organik Fındık ÜB'nin girdi temini, ürün pazarlama ve eğitim hizmetlerini üyelerle aynı şartlarda üye olmayan çiftçilere de sağladıkları belirlenmiştir. Cook (1995), tarımsal kooperatiflerin üyelerine sağladığ hizmetlerden üye olmayanların da yararlanmasının, kooperatif üyelerinde isteksizlik yaratacağını vurgulamaktadır.

Tarımsal örgütlerin daha etkili hale gelebilmesi, kırsal alanda üyelere verilecek hizmetlerin, örgütlerin sermayelerinin güçlendirilebilmesi, üye-örgüt ilişkilerinin, üyelerin tarımsal gelirlerinin ve üye memnuniyetinin artırılabilmesi için projeye dayalı faaliyetlerinin geliştirilmesi gerekli görülmektedir (Kılıç Topuz ve Bozoğlu, 2015). Araştırma kapsamında ele alınan birliklerin herhangi bir proje başvurusunun olmadığı belirlenmiştir. Birliklerin üyelerine verdikleri hizmetleri, piyasada rekabet güçlerini, gelirlerini artırabilmesi için proje hayata geçirmeleri gerekmektedir. $\mathrm{Bu}$ sebeple, birlik yöneticileri ve çalışanlarına proje hazırlama, yazma ve proje kaynağı konusunda eğitim verilerek, bilgi ve beceri eksikliğinin giderilmesi gerektiği açıkça görülmektedir. 
Çizelge 6. Birliklerin üyelerine sağladıkları hizmetler ve üyelerin bu hizmetlerden yararlanma durumları

\begin{tabular}{|c|c|c|c|c|}
\hline Hizmetler & $\begin{array}{c}\text { Çarşamba } \\
\text { Organik Findık } \\
\text { TÜB }\end{array}$ & $\begin{array}{c}19 \text { Mayıs } \\
\text { Organik Findık } \\
\text { TÜB }\end{array}$ & $\begin{array}{c}\text { Terme Organik } \\
\text { Findık TÜB }\end{array}$ & $\begin{array}{c}\text { Üyelerin } \\
\text { yararlanma } \\
\text { durumu (\%) }\end{array}$ \\
\hline Çiftçi kaydı & Evet & Evet & Evet & 100.0 \\
\hline Tarımla ilgili eğitim ve danışmanlık & Evet & Evet & Evet & 42.4 \\
\hline Üretici örgütlenmesi eğitimi & Evet & Evet & Hayır & 8.6 \\
\hline Ürün pazarlamaya aracılık & Evet & Evet & Evet & 54.3 \\
\hline İhracata aracılık & Evet & Evet & Evet & 38.1 \\
\hline Girdi temininde yönlendirici yardım & Evet & Evet & Evet & 1.1 \\
\hline Girdi temini & Hayır & Evet & Hayır & 1.1 \\
\hline Gazete, dergi vb. basılı materyal & Evet & Evet & Evet & - \\
\hline Sosyo-kültürel etkinlikler & Evet & Evet & Hayır & - \\
\hline Üretimle ilgili araç-gereç & Hayır & Evet & Hayır & - \\
\hline Fındık alanlarının ruhsatlandırılması & Hayır & Evet & Hayır & - \\
\hline Birliklerin web sitesi varlığ 1 & Evet & Hayır & Hayır & - \\
\hline Üye olmayan üreticilere hizmet sağlama & Evet & Hayır & Hayır & - \\
\hline
\end{tabular}

\section{Birliklerin Sorunları}

Birliklerin en önemli sorunları; fındık üretimindeki kayıt dışılık ve birlik sermayesinin yetersiz olması şeklindedir. Birliklerin diğer sorunları ise sırasıyla; devlet desteğinin yetersiz olması, aracıların fındık piyasasında rekabette üstün olmaları, birliklerin denetim eksikliği, tarımsal desteklerin birlikler aracılığıyla verilmemesi, birlik hizmetlerinin yetersiz olması ve üyelik aidatlarının düzenli olarak ödenmemesi şeklindedir (Çizelge 7).

Birlik yöneticilerinin bu sorunların çözümünde devletten beklentileri ise tarımsal desteklerin birlik aracılığıyla ödenmesi, bakanlık kararlarında birliklerinde fikrinin alınması gerektiği, 5200 Sayılı Kanun'un değiştirilerek, birliklerin kendi mülkiyetine araç-gereç satın alabilmesi ve ürün pazarlayabilmesi ve organik üreticilerin tamamının ÇATAK desteği alması şeklindedir. Çiftçi (2015) tarafından Konya ilinde yapılan araştırmada da Damızlık Koyun Keçi yetiştirici birliğinin temel sorunlarının politik, ekonomik, sosyokültürel, teknolojik, etik ve yasal sorunlardan oluştuğu belirlenmiştir. Sağlam ve İnan (2014) tarafından yapılan araştırmada Uşak ilindeki tarımsal üretici örgütlerinin en önemli sorunlarının yasal sorunlar, yöneticilerin kooperatifçilik ve işletmecilik konusunda yeterli bilgiye sahip olmamaları, finansman, denetim ve eğitim olduğu, Serinikli ve Kumkale (2012) tarafından yapılan araştırmada ise kooperatif üst örgütlerinin en önemli sorunlarının finansman, mevzuat ve ortakların ilgisizliği olduğu belirlenmiştir. 
Çizelge 7.Birliklerin sorunları

\begin{tabular}{|c|c|c|c|c|c|}
\hline $\begin{array}{l}\text { Birliklerin } \\
\text { sorunları }\end{array}$ & 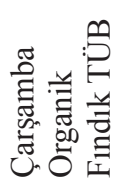 & 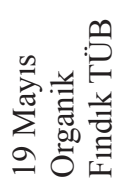 & 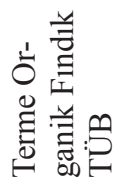 & 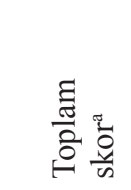 & 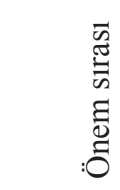 \\
\hline Kayıt dışı üretim & 5 & 5 & 5 & 15 & 1 \\
\hline Birlik sermayesinin (işletme sermayesi) yetersizliği & 5 & 5 & 5 & 15 & 1 \\
\hline Devlet desteğinin yetersizliği & 4 & 5 & 5 & 14 & 2 \\
\hline Aracıların rekabette üstün olması & 3 & 5 & 5 & 13 & 3 \\
\hline Birliklerin denetim eksikliği & 3 & 4 & 5 & 12 & 4 \\
\hline Tarımsal desteklerin birlik aracılığıyla verilmemesi & 1 & 5 & 5 & 11 & 5 \\
\hline Birliğin hizmetleri yetersiz & 1 & 5 & 5 & 11 & 5 \\
\hline Üyelik aidatlarının düzenli olarak ödenmemesi & 5 & 1 & 4 & 10 & 6 \\
\hline Yetersiz tarım danışmanı/danışman bulamamak & 2 & 5 & 1 & 8 & 7 \\
\hline Ürünlerin pazarlanamaması & 1 & 1 & 5 & 7 & 8 \\
\hline Niteliksiz personel/danışman & 1 & 5 & 1 & 7 & 8 \\
\hline İyi tarım fiyat farkı yok, organik üründe rekabet yok & 1 & 5 & 1 & 7 & 8 \\
\hline Alan bazlı findık desteklemesi & 5 & 1 & 1 & 7 & 8 \\
\hline Birlik-üye arasında güven eksikliği & 3 & 1 & 1 & 5 & 9 \\
\hline Üyelerin eğitim seviyesi ve örgütlenme bilinci düşük & 1 & 1 & 2 & 4 & 10 \\
\hline 5200 Sayılı Kanun & 2 & 1 & 1 & 4 & 10 \\
\hline
\end{tabular}

a Toplam skor, yöneticilerin birliklerin sorunları ile ilgili her bir soruya verdikleri cevapların ağırlıklıtoplamları alınarak hesaplanmıştır. Yöneticilerin birliklerin sorunları hakkındaki görüşleri 1 (Önemsiz)'den 5 (Önemli)'e kadar değişmektedir.

\section{SONUÇ}

Samsun İli, Türkiye'de en fazla fındık yetiştiren illerden biridir. Samsun İlinde yetiştirilen fındığın yaklaşık 1/4’ünü sağlayan diğer ilçelerde fındık konusunda faaliyet gösteren herhangi bir tarımsal örgüt bulunmamaktadır. Fındık üretiminin olduğu fakat fındık konusunda faaliyet gösteren herhangi bir tarımsal örgüt bulunmayan diğer ilçelerde de örgüt kurulmalıdır.

Mevcut birlik üyelerinin yaklaşı $1 / 3$ 'ü aktif değildirler. Birliklerin yaklaşık 2/3'ünde üyelerden giriş sermayesi alınmamakta, üyelerin yaklaşık yarısı ise birliklerine aidat ya hiç ödememekte ya da ara sira ödemektedirler. $\mathrm{Bu}$ da birliklerin gelirlerinin ve dolayısıyla üyelerine sağladıkları hizmetlerin azalmasına sebep olmaktadır. Üyelerin giriş sermayesi ve üyelik aidatı ödeme oranlarının artırılabilmesi için birliklerin özellikle girdi temini ve ürün pazarlanması konusunda aktif olarak rol alması ve bu konuda üreticilere eğitim düzenlenmesi kaçınılmazdır.

Birliklerin en önemli sorunları; fındık üretimindeki kayıt dışı üretim, birliklerin gelirlerinin yetersiz olması, aracılarla rekabet edememeleri, üyelik aidatlarının düzenli olarak ödenmemesi ve üyelerin birliklerine yeterince güvenmemeleri şeklindedir. $\mathrm{Bu}$ sorunların çözümünde en önemli araç birliklerin performanslarının artırılmasıdır. Fındık TÜB'nin performanslarının artırılması için ise; birliklerin ürün pazarlama, ihracat ve girdi temininde daha aktif olması, üyelere teknik yardım sağlaması, üyelerin ise sorumluluklarını yerine getirmeleri gerekli görülmektedir. TÜB'nin en önemli sorunu olarak görülen sermaye yetersizliğinin giderilebilmesi için öncelikli olarak projeye dayalı ulusal ve uluslararasi desteklerden yeterince 
yararlanabilmeleri gerekli görülmektedir. Bu sayede performansı artan birlikler, üyelerine daha fazla hizmet götüreceğinden üyelik aidatı toplayamama, birlik hizmetlerinin yetersiz olması ve birlik-üye arası güven eksikliği sorununa çözüm getirilebilecektir. Bu durum birliklerin gelirinin daha da artmasına sebep olacaktır. Geliri artan birlikler, piyasada daha güçlü konuma gelecek ve aracılara karşı rekabet üstünlüğü artacağından ürün fiyatının artırılmasına da etkileri olabilecektir. Ayrıca birlik üyelerine üyelik aidatlarının önemi konusunda eğitimler düzenlenmeli, üyelerin bu konudaki bilgi düzeyleri artırılmalıdır.

Birlik yöneticilerinin eğitim seviyesi oldukça düşüktür. Birliklerin daha başarılı olabilmeleri için yönetimindeki kişilerin eğitim seviyesi daha yüksek kişilerden oluşması ve tarımsal örgütlenme ile ilgili daha fazla eğitimlere katılmaları gerekli görülmektedir. Örgütlenme bilinci düşük olan üreticilerin sorunu ise eğitimle giderilebilecektir. $\mathrm{Bu}$ konuda sadece birlik üyelerine değil birlik yöneticilerine de tarımsal örgütlenme konusunda eğitim verilmelidir. Bakanlık

\section{KAYNAKLAR}

Acar İ, Yıldırım İ, 2000. Mandıra işleten Dönerdere tarımsal kalkınma kooperatifine ortak işletmelerin ekonomik analizi. Yüzüncü Yıl Üniversitesi, Ziraat Fakültesi, Tarım Bilimleri Dergisi, 10 (1): 61-70.

Anonim, 2004. 5200 sayılı Tarımsal Üretici Birlikleri Kanunu, 06.07.2004 tarih 25514 Say1l Resmi Gazete, http:/www. resmigazete.gov.tr/default.aspx (Erişim Tarihi: 10.01.2018).

Anonim, 2014. Samsun Gıda, Tarım ve Hayvancılık İl Müdürlüğü kayıtları (Erişim Tarihi: 4.01.2017).

Anonim, 2015. Resmi Gazete, 30.05.2015 tarih 29371 Sayılı Kanun, Tarımsal Yayım ve Danışmanlık Hizmetlerine Destekleme Ödemesi Yapılması Hakkında Tebliğ (Erişim Tarihi: 5.04.2017).

Anonim, 2016a. Resmi Gazete, 10 Ekim 2016 tarih 29853 Sayıl Kanun, Tarımsal Yayım ve Danışmanlık Hizmetlerine Destekleme Ödemesi Yapılması Hakkında Tebliğg, http://www. resmigazete.gov.tr/eskiler/2016/10/20161010-2.htm (Erişim Tarihi: 29.05.2017).

Anonim, 2016b. Türkiye İstatistik Kurumu, Bitkisel üretim istatistikleri, İlçelere göre üretim istatistikleri, https://biruni. tuik.gov.tr/bitkiselapp/bitkisel.zul (Erişim Tarihi: 16.03.2017).

Anonim, 2017. Türkiye İstatistik Kurumu, Bitkisel üretim istatistikleri,

https://biruni.tuik.gov.tr/bitkiselapp/bitkisel.zul (Erişim Tarihi: 16.03.2017)

Anonymous, (2014a). Food and Agriculture Organization. http:// www.fao.org/faostat/en/\#data (Date of access: 5 February 2018). ve üniversitelerden bu konuda sürekli yardım alınması gerekli görülmektedir.

Birlikler ilgili kanunda belirtilen görevlerin büyük çoğunluğunu yerine getirmesine rağmen, üyelerine girdi temini ve teknik destek gibi görevlerini etkili bir şekilde yerine getirmedikleri tespit edilmiştir. Birliklerin üyelerine ürün pazarlamaya ve ihracata aracılık, eğitim, yayım ve danışmanlık hizmetleri ve girdi temininde yönlendirici yardımlarda bulunmak gibi hizmetleri sağlamasına rağmen, birlik üyelerinin bu hizmetlerden yararlanma oranları oldukça düşüktür. Birliklerin $1 / 3$ 'ü üye olmayan üreticilere de hizmet sağlamaktadırlar. Birlikler mevcut imkânlarını sadece üyelere sağlamalı, diğer üreticiler de örgütlere üye olmaya teşvik edilmelidir. Birliklerin çoğunluğunun web sitesi olmadığ 1 veya web sitelerinin aktif olarak kullanılmadığı belirlenmiştir. Birliklerin faaliyetlerini daha etkili olarak yapabilmeleri ve özellikle yurt dış1 tanıtımlarının yapılabilmesi için aktif olarak kullanılan web sitelerinin bulunması gerekli görülmektedir.

Anonymous, (2014b). United States Department of Agriculture, Turkey Tree Nuts Annual Report 2014, (Date of access: 10 April 2018).

Başaran B, 2003. Uluslararası Çalışma Örgütü'nün Yeni Kooperatif Standartları ve Ülkemiz Kooperatiflerinin Uyumu: Trakya Bölgesi Tarım Kooperatifleri Örneği. Trakya Üniversitesi, Fen Bilimleri Enstitüsü, Yüksek Lisans Tezi, 119s.

Bozoğlu M, Cinemre H, Ceyhan V, 2001. Tarımsal sanayinin geliştirilmesinde kooperatifleşme: Tonya örneği. Ondokuz Mayıs Üniversitesi, Ziraat Fakültesi Dergisi, 16(2): 23-29.

Cook ML, 1995. The Future of U.S. Agricultural Cooperatives: A Neo-Institutional Approach. American Journal of Agricultural Economics, 77(5): 1153-1159.

Çiftçi İ, 2015. Damızlık Koyun-Keçi Yetiştiricileri Birliklerinin Sürdürülebilir İşletmecilik Modeli: Konya İli Örneği. Selçuk Üniversitesi, Fen Bilimleri Enstitüsü, Yüksek Lisans Tezi, 86s.

Çukur F, Saner G, 2012. Süt sığırcılığının geliştirilmesinde birliklerin rolü ve önemi: Milas ilçesi süt üreticileri birliği örneği. X. Tarım Ekonomisi Kongresi, 5-7 Eylül 2012, Konya.

Doğan H.G, 2011. Türkiye'deki Üretici Birliklerinin Üretici Örgütlenmesinde Yeri ve Önemi (Kazova Bölgesi Yaş Sebze Ve Meyve Üreticileri Birliği Örneği. Gaziosmanpaşa Üniversitesi, Fen Bilimleri Enstitüsü, Yüksek Lisans Tezi, 114 s.

Erkuş A, Özüdoğru H, 2005. Köy-Koop Kırklareli Birliği’nin ekonomik analizi ve yöneticilerinin kooperatif işletmelerinin başarısına etkilerinin değerlendirilmesi. Üçüncü Sektör Kooperatifçilik Dergisi, 150: 3-22. 
Ertan A, Turan A, 2001. GÜLBİRLİK ortaklarının kooperatif ortak ilişkisi yönünden analizi. Süleyman Demirel Üniversitesi, İktisadi ve İdari Bilimler Fakültesi Dergisi, 6(2): 29-43.

Everest B, 2009. Tarımsal Ürünlerin Pazarlanmasında Çiftçi Örgütlerinin Rolü ve Önemi: Çanakkale Tarımsal Kalkınma Kooperatifleri Örneği. Çanakkale Onsekiz Mart Üniversitesi, Fen Bilimleri Enstitüsü, Yüksek Lisans Tezi, 76s.

European Commission, 2002. Project Cycle Management Handbook. http://www.sle-berlin.de/files/sletraining/PCM Train_Handbook_EN-March2002.pdf (Date of access: 3 May 2018).

Güreşçi E, 2010. Tarımsal kalkınmada tarımsal üretici birliklerinin önemi: İspir Bal Üretici Birliği örneği. IX. Tarım Ekonomisi Kongresi, 22-24 Eylül 2010, Şanlıurfa.

Karami E, Moghaddam K.R, 2005. Modeling determinants of agricultural production cooperatives' performance in Iran. Agricultural Economics, (33): 305-314.

Karlı B, Çelik Y, 2003. GAP alanındaki tarım kooperatifleri ve diğer çiftçi örgütlerinin bölge kalkınmasındaki etkinliği. 116, Yayın no: 97 ISBN 975-407-122-5, Şanlıurfa.

Kılıç B, 2011. Samsun İlindeki Tarımsal Kalkınma Kooperatiflerinde Ortak-Kooperatif İlişkilerinin Analizi. Ondokuz Mayıs Üniversitesi, Fen Bilimleri Enstitüsü, Yüksek Lisans Tezi, 158 s.
Kılıç Topuz B, Bozoğlu M, 2015. Samsun İlindeki Tarımsal Kalkınma Kooperatiflerinde Ortak-Kooperatif İlişkilerinin Analizi. Anadolu Tarım Bilimleri Dergisi, 30(3): 246-253.

Özüdoğru H, 2004. Köy-Koop Kırklareli Birliği'nin Ekonomik Analizi ve Yöneticilerin Kooperatif İşletmelerinin Başarısına Etkilerinin Değerlendirilmesi. Ankara Üniversitesi, Fen Bilimleri Enstitüsü, Doktora Tezi.

Rehber E, 2006. Tarımda Yeni Nesil Kooperatifler. Tarım ve Köyişleri Bakanlığı, Türktarım Dergisi, 171: 40-43.

Sağlam U, İnan İH, 2014. Uşak ilindeki üreticilerin tarımsal üretici örgütlenmesi ve sorunları hakkındaki bilgi düzeyleri. XI. Ulusal Tarım Ekonomisi Kongresi 3-5 Eylül 2014, Samsun.

Serinikli N, Kumkale İ, 2012. Türkiye'deki Kooperatif Üst Örgütlerinin (Bölge Birliklerinin) Sorunları ve Çözüm Önerileri. Trakya Üniversitesi Sosyal Bilimler Dergisi, 14(1): 269-290.

Yamane T, 1967. Elemantary Sampling Theory. Prentice Hall Inc., Englewoods, New Jersey. 